\title{
Nursing students: the use of digital social network to profile nurses
}

\author{
Egressos de enfermagem: o uso da rede social digital para traçar o perfil dos enfermeiros \\ Graduados en enfermería: el uso de la red social digital para perfilar enfermeras
}

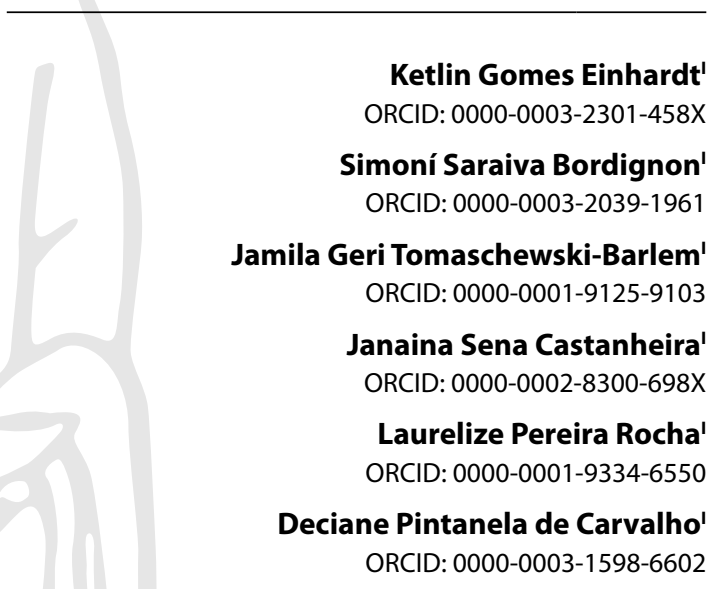

'Universidade Federal de Rio Grande. Rio Grande, Rio Grande do Sul, Brazil.

How to cite this article: Einhardt KG, Bordignon SS, Tomaschewski-Barlem JG, Castanheira JS, Rocha LP, Carvalho DP. Nursing students: the use of digital social network to profile nurses. Rev Bras Enferm. 2022;75(4):e20200865 https://doi.org/10.1590/0034-7167-2020-0865

Corresponding author:

Simoní Saraiva Bordignon

E-mail: simonibordignon@gmail.com

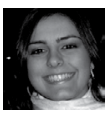

EDITOR IN CHIEF: Dulce Barbosa ASSOCIATE EDITOR: Ana Fátima Fernandes

Approval: 11-02-2021

\section{ABSTRACT}

Objectives: to analyze the profile of nursing students at a university in southern Brazil and verify the effectiveness of the use of social networks in students'location and adherence. Methods: a quantitative, descriptive and exploratory study, carried out with 314 students through a questionnaire prepared on Google Forms, made available through digital social networks and e-mails. Results: students were women, without training in a technical/assistance nursing course, participants in projects and research groups, with a graduate degree. Furthermore, more than $75 \%$ obtained their first job within six months after graduation, more than $80 \%$ worked in healthcare, with public employment, workload of up to 40 hours a week, income between four and ten minimum wages, and $92 \%$ indicated that they were satisfied and/or very satisfied with the course. Conclusions: the strategic use of social networks enabled greater adherence by the target audience and nursing students' profile design.

Descriptors: Education, Nursing; Social Networking; Nurses, Male; Nursing; Employment.

\section{RESUMO}

Objetivos: analisar o perfil dos enfermeiros egressos de uma universidade do sul do Brasil e verificar a efetividade do uso das redes sociais na localização e adesão dos egressos. Métodos: estudo quantitativo, descritivo e exploratório, realizado com 314 egressos através de questionário elaborado no Google Forms, disponibilizado por redes sociais digitais e e-mails. Resultados: 0 perfil dos egressos foi de mulheres, sem formação em curso técnico/auxiliar de enfermagem, participantes de projetos e grupos de pesquisa, com pós-graduação. Ainda, mais de $75 \%$ obtiveram o primeiro emprego em até seis meses após a formatura, mais de $80 \%$ atuavam na área assistencial, com vínculo empregatício público, carga horária de até 40 horas semanais, renda entre quatro e dez salários mínimos e 92\% indicaram estarem satisfeitos e/ou muito satisfeitos com o curso. Conclusões: o uso estratégico das redes sociais possibilitou maior adesão do público-alvo e o delineamento do perfil do egresso de enfermagem.

Descritores: Educação em Enfermagem; Rede Social; Enfermeiros; Enfermagem; Emprego.

\section{RESUMEN}

Objetivos: analizar el perfil de los enfermeros graduados de una universidad del sur de Brasil y verificar la efectividad del uso de las redes sociales para localizar e incorporar a los graduados. Métodos: estudio cuantitativo, descriptivo y exploratorio, realizado con 314 graduados a través de un cuestionario elaborado en Google Forms, disponible a través de redes sociales digitales y correos electrónicos. Resultados: el perfil de los graduados fue de mujeres, sin formación en un curso técnico/auxiliar de enfermería, participantes en proyectos y grupos de investigación, con posgrado. Además, más del $75 \%$ consiguió su primer trabajo dentro de los seis meses posteriores a la graduación, más del $80 \%$ trabajó en el área de cuidado, con empleo público, carga de trabajo de hasta 40 horas semanales, ingresos entre cuatro y diez salarios mínimos, y el $92 \%$ indicó estar satisfecho y/o muy satisfecho con el curso. Conclusiones: el uso estratégico de las redes sociales permitió una mayor adhesión del público objetivo y el diseño del perfil de egresado de enfermería.

Descriptores: Educación en Enfermería; Red Social; Enfermeros; Enfermería; Empleo. 


\section{INTRODUCTION}

The number of nursing students in Brazil is growing significantly. In 2014, the accumulated number of new professionals was 444,596 thousand; in the next three years, there was an increase of 23,186 active nurses ${ }^{(1)}$. The requirements related to the profile of these professionals are constantly changing, considering the needs of the Unified Health System (Sistema Único de Saúde) and the labor market. Thus, the organization and improvement of the professionals' training process are essential for the development and maintenance of the Brazilian health system ${ }^{(2)}$. To this end, the 2001 Brazilian National Curriculum Guidelines for the Nursing Course (DCNs - Diretrizes Curriculares Nacionais) have as a guiding axis a profile of generalist, humanist, critical and reflective nursing students, who meet social, epidemiological and health needs ${ }^{(3)}$.

In this sense, it is necessary to carry out continuous assessments of the training processes developed in undergraduate nursing courses ${ }^{(4)}$, using different methodologies and audiences, including students, in order to contextualize the pedagogical projects with the reality of the work in which they are inserted ${ }^{(5)}$. Thus, the higher education institution that is concerned with monitoring its students demonstrates a critical vision, the ability to question, propose new plans and solve unsatisfactory aspects during the training period ${ }^{(6)}$.

Still, research ${ }^{(5-6)}$ emphasizes the importance of presenting the perspectives of students as evaluators of their educational process and insertion in the labor market in the assessment system of educational processes, because, based on their own experience, they become sources of extremely relevant information. However, when conducting studies with students, there are challenges in contacting them and in returning the answers back to the questionnaires during the data collection period ${ }^{(5,7-10)}$. These challenges arise for different reasons; some of them may be related to outdated or non-existent information about students in previous registrations, emails classified as spam and students' low adherence to answering and sending the questionnaires. A facilitating resource in this context is the use of digital communication technologies and digital social networks, which contribute, through data collection, as they are a differential in the search process and research adherence, due to the system speed and versatility, enabling remote online monitoring of students $s^{(5,11)}$.

In this regard, studies with undergraduate nursing students show gaps in the literature related to the university's contribution to professional life, the activities carried out in the training process, the time to enter the labor market and the degree of satisfaction with training ${ }^{(5)}$, often due to strategic difficulties in locating and receiving data from their students ${ }^{(5,7-10)}$ justifying this study. For this purpose, the following research questions were defined: what is the profile of nursing student in the undergraduate nursing course at a university in southern Rio Grande do Sul and how effective is the use of social networks in students' location and adherence?

\section{OBJECTIVES}

To analyze the profile of nursing students at a university in southern Brazil and verify the effectiveness of the use of social networks in students' location and adherence.

\section{METHODS}

\section{Ethical aspects}

The ethical and scientific requirements recommended for research with human beings were ensured, through Resolution $510 / 2016$, and the project was evaluated and approved by the Research Ethics Committee (REC/FURG), under Opinion 36/2019.

\section{Study design, period, and place}

This is a descriptive, exploratory study with a quantitative approach. It was carried out from August 3, 2019 to September 16, 2019 , totaling 45 days, through the use of digital tools to send the questionnaires prepared on Google Forms.

The study was carried out with nursing students from a federal university in southern Rio Grande do Sul. Currently, the course has a duration of ten academic semesters. The admission modality is through the unified selection system (SISU/ENEM) with double admission, with 30 semiannual places. The course has morning and afternoon shifts.

\section{Population, sample; inclusion and exclusion criteria}

The study sample consisted of 314 nursing students from the undergraduate nursing course, from 1979 to 2019 , totaling 1,123 students. The sample size was defined by a specific mathematical formula ${ }^{(12)}$, establishing a minimum number of 289 participants to ensure the study reliability. The following inclusion criteria were adopted: having completed the undergraduate nursing course from 1979 to 2019. As exclusion criteria: health conditions that make it impossible to complete the questionnaire, if they do not have access to the internet.

\section{Study protocol}

Data collection organization was developed in three stages: planning, preparation of material and adherence strategies through the use of digital tools. In the planning, the following were detailed: action plans and deadlines; the choice of Google Forms digital technology for the elaboration of the questionnaire, as it is a free online platform, which offers support for the creation of personalized forms; the creation of arts (visual pieces) from digital design, with the aim of promoting and inviting participants; the choice of digital social networks Facebook, WhatsApp and Instagram; and the use of e-mails and the institutional website, with the entire process aiming at greater coverage and adherence of student participants.

In the stage of material preparation, at first: the questionnaire on Google Forms, which addressed identification, sociodemographic characteristics, undergraduate and graduate data, characterization of insertion and professional trajectory through questions about professional performance, employment relationship(s), working hours, wage range, and also the one item that allowed students to express their level of satisfaction with the undergraduate course in a Likert-type scale format, from one to five, in which one means "Totally dissatisfied", and five, "Totally satisfied".

In the second moment, the visual pieces were developed in two proposals, aiming at different audiences. Thus, a formal model was 
used - from the color green, which refers to the nursing profession and a clear image of a woman at work with social clothes - and another with a casual approach - from the orange color, which refers to the researched institution and an image of a moving woman in usual clothes. Each visual piece contained an explanatory text with the approach according to the proposals, formal and informal. Both included the address of the questionnaire, which was also adapted using the Bit.Ly tool to make it smaller and visually simpler, as shown in Figure 1.
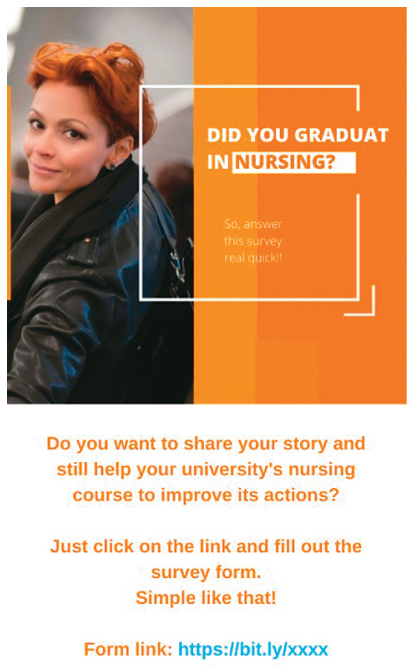

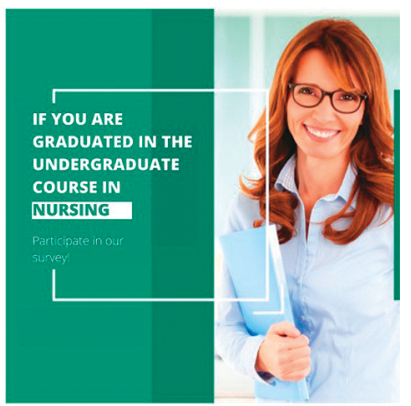

Over the years, how many people have entered as students and graduated with bachelor's degrees in nursing from our course? Many of them!

If you are one of them, we want to hear your story. Just fill out the survey form and you'll be helping to build a better Form link: https://bit.ly/xxx course for students to come!

Figure 1 - Visual arts for dissemination and invitation of participants

In the third stage, dissemination strategies were carried out through the use of digital tools. The visual pieces were made available on digital social networks such as WhatsApp, which allowed individual and group sharing with the course students. Disclosure to other students/groups was also requested.

Similarly, on the digital social network Facebook, the visual pieces were sent, individually, through nominal marking, posted on the Facebook page of the researched undergraduate nursing course and in communities of students, encouraging public sharing with others, aiming at greater dissemination of the research. Also, sentinel profiles were selected, that is, people who were also graduates of the nursing course were contacted and invited to share the visual pieces and invite their colleagues in their WhatsApp group groups and on their personal Facebook pages.

The Facebook sponsorship feature was also used, which is a paid tool that directs the post to those users who have the selected characteristics. For this purpose, the criteria indicated were age between 22 and 50 years, Brazil region, Rio Grande do Sul, interest in nursing and in the researched university. Thus, the results were quantified at a rate of 33,659 impressions, meaning that 16,976 people viewed the post twice on average in their timeline and, of these, 645 (1.92\%) interacted through clicks, likes, comments and shares. Also, invitations were sent via Messenger in a private message.

In addition to the strategies used in the digital social networks for dissemination, the visual pieces were sent by email, through a list with students' names and their respective contacts obtained from the nursing school department, and publication on the researched university's institutional website.

\section{Analysis of results}

After filling in the online questionnaires, the answers immediately appeared on the Google Forms page of the person responsible for the research and were tabulated in an Excel 365 spreadsheet. Data analysis was performed using descriptive statistics, using the mean, minimum and maximum, absolute frequency and relative frequency of responses to the study questionnaires.

\section{RESULTS}

The instrument was available for 45 days, a period in which the minimum sample size established for this study was reached, representing almost $1 / 3$ of the study population. A total of 320 responses to the instrument were obtained. Of these, six were excluded: two for being blank and four for not having completed their undergraduate degree in nursing at the time of data collection. Thus, 314 students participated in this study.

\section{Student characterization}

The sample consisted of 314 nursing students from the undergraduate nursing course: 289 (92\%) were female, with a mean age of 36 years, ranging between 21 and 63 years; 272 (86.6\%) were from the extreme south of Rio Grande do Sul, Brazil, with emphasis on the cities of Rio Grande, Pelotas and Santa Vitória do Palmar, and most students, 272 (86.6\%), did not have training as a nursing assistant/technician.

Regarding training in another undergraduate course, before entering the nursing course, ten (3.2\%) students had obtained it and, of these, only one was related to the health area: a technologist in hospital management and health. Thus, 22 (7\%) indicated the completion of another graduation concurrently with the graduation in nursing, of these, 21 (6.7\%) were related to the nursing course, teaching license in nursing and degree in nursing. Moreover, nine completed another degree after completing their graduation in the nursing course, two of which were related to a teaching license in nursing and a degree in nursing.

\section{Profile of nursing students in the professional training process}

Regarding the average age of participants when entering the undergraduate course, it was 21 years old, ranging between 16 and 51 years old, with a predominance of 17 and 19 years old. The way to enter the course was through entrance examination (237;75.5\%). Regarding the year of entry of participants, the period was between 1976 and 2019, with emphasis on 2004 with 25 (8\%) participants, followed by 2009 with 23 (7.3\%). The year of graduation was 2014 with 31 (9.9\%), followed by 2008 with 24 (7.6\%) students.

The students indicated that they had participated in teaching, research and extension projects during the undergraduate nursing course, highlighting the participation of 233 (74.2\%) students in research projects, $231(73.6 \%)$ in extension projects and $206(65.6 \%)$ in teaching projects. In relation to receiving a scholarship to carry out these activities, 222 (70.7\%) participants indicated that they had received it.

Participation in research groups was reported by 201 (64\%) of the students. Among the most cited, 65 (32.3\%) stand out 
from the Núcleo de Estudo e Pesquisas em Enfermagem e Saúde (NEPES) research group, followed by 51 (25.4\%) from the Viver Mulher group. Also, among the students, ten (3.2\%) performed academic mobility through exchange, of these, eight performed international exchange and two of them national exchange.

After graduating in nursing, most students completed graduate studies 263 (83.8\%), with emphasis on Lato Sensu (241; 91.6\%) and $(204 ; 84.6 \%)$ specialization. The most sought after institutions for the courses were the Universidade Federal do Rio Grande and the Universidade Federal do Rio Grande do Sul.

Thus, 184 (70\%) students went through Stricto Sensu training; of these, $111(60.3 \%)$ had an academic master's degree, and 60 (32.6\%) had a doctoral degree. The most sought after national institutions were the Universidade Federal do Rio Grande (117; $63.6 \%)$, the Universidade Federal de Pelotas (18; 9.8\%) and the Universidade Federal de Santa Catarina (9;4.9\%). Furthermore, Harvard University, in the United States, the University of Bordeaux, in France, and the National Technological University, in Argentina, stand out, as shown in Table 1.

Table 1 - Distribution of variables related to the education process of students at a university in southern Brazil, Rio Grande, Rio Grande do Sul, Brazil, 2019

\begin{tabular}{lcc}
\hline Variables & $\mathbf{n}$ & $\%$ \\
\hline Performance during graduation & & \\
$\quad$ Research project & 233 & 74.2 \\
$\quad$ Extension project & 231 & 73.6 \\
$\quad$ Teaching project & 206 & 65.6 \\
$\quad$ Research group & 201 & 64.0 \\
Paid scholarship at graduation & & \\
Yes & 222 & 70.7 \\
$\quad$ No & & \\
Graduate degree & & \\
Yes & 263 & 83.8 \\
$\quad$ No & & \\
Stricto Sensu & & \\
Academic master's degree & 111 & 60.3 \\
$\quad$ Professional master's degree & 7 & 3.8 \\
$\quad$ Doctoral degree & 60 & 32.6 \\
Post-doctoral & 6 & 3.3 \\
Lato Sensu & & \\
$\quad$ Specialization & 204 & 84.6 \\
Residency program & 37 & 15.4 \\
\hline
\end{tabular}

\section{Profile of nursing students in their insertion and perfor- mance in the labor market}

Regarding the time it took students to find their first job, it is highlighted that 92 (29.3\%) were employed before completing their graduation and 146 (46.5\%) were employed until six months after graduation. Regarding experience time as a nurse, most (118;37.6\%) students worked between 10 and 20 years, as shown in Table 2 .

At the time of the survey, 262 (83.4\%) students reported working professionally as nurses and $52(16.6 \%)$ did not. Therefore, in relation to the majority, 14 (26.9\%) do not work, because they are taking a graduate course, $12(23.1 \%)$, because they work as a nursing assistant/technician, seven (13.5\%), for being retired as nurses, six (11.5\%), for changing their area of expertise. Still, among those who do not work, 25 (48\%) reported never having acted.

The current employment relationship or where most of the professional activity remained was answered by 289 (92\%) of the nursing students, of which 150 (51.9\%) work as public servants and 103 (35.6\%) work in a private company. Regarding the area and place of work where nurses currently perform their activities or develop most of their professional experience, 150 (51.9\%) were in hospital institutions and 85 (29.4\%) in educational institutions, with load current weekly hours or in which most of their professional activities remained, 133 (46\%) work for 40 hours a week. Still, most students indicated that they work or have worked (230; 79.5\%) in the state of Rio Grande do Sul.

Table 2 - Distribution of variables related to the performance of students at a university in southern Brazil, Rio Grande, Rio Grande do Sul, Brazil, 2019

\begin{tabular}{lcc}
\hline Variables & $\mathbf{n}$ & $\%$ \\
\hline Time to find first job & & \\
Guaranteed employment at the end of graduation & 92 & 29.3 \\
First 6 months & 146 & 46.5 \\
6 to 12 months & 24 & 7.6 \\
1 to 2 years & 11 & 3.5 \\
More than 2 years & 19 & 6.1 \\
Still have not had it & 16 & 5.1 \\
Never sought & 6 & 1.9 \\
Performance time & & \\
Never worked & 25 & 8.0 \\
Up to 5 years & 94 & 29.9 \\
Between 5 and 10 years & 57 & 18.2 \\
10 and 20 years & 118 & 37.6 \\
20 and 30 years old & 14 & 4.4 \\
Over 30 years & 6 & 1.9 \\
\hline
\end{tabular}

Table 3 - Distribution of variables related to the work characteristics of students at a university in southern Brazil, Rio Grande, Rio Grande do Sul, Brazil, 2019

\begin{tabular}{lcc}
\hline Variables & $\mathbf{n}$ & $\%$ \\
\hline Area/place of work* & & \\
Hospital institutions & 150 & 51.9 \\
Educational institutions & 85 & 29.4 \\
Primary health care networks & 83 & 28.7 \\
Public administration agencies & 23 & 8.0 \\
Private clinics & 18 & 6.2 \\
Research institution & 14 & 4.8 \\
Other forms of care & 14 & 4.8 \\
Work dimensions* & & \\
Care work & 226 & 78.2 \\
Administrative performance & 106 & 36.7 \\
Teaching activities & 95 & 32.9 \\
Research activities & 50 & 17.3 \\
Activities in political participation & 13 & 4.5 \\
Work relationship & & \\
Public workers & 150 & 51.9 \\
Private companies & 103 & 35.6 \\
Temporary contract & 24 & 8.3 \\
Self-employed & 12 & 4.2 \\
Weekly working hours & & \\
20 hours a week & 2 & 0.7 \\
30 hours a week & 48 & 16.6 \\
36 hours a week & 62 & 21.5 \\
40 hours a week & 133 & 46.0 \\
44 hours a week & 27 & 9.3 \\
More than 44 hours a week & 17 & 5.9 \\
Monthly income & & \\
Up to 2 minimum wages & 18 & 6.2 \\
2 to 4 minimum wages & 83 & 28.7 \\
4 to 10 minimum wages & 152 & 52.6 \\
10 to 20 minimum wages & 32 & 11.1 \\
Above 20 minimum wages & 4 & 1.4 \\
\hline
\end{tabular}

*The total is greater than that of participants (314), as in some variables it was possible to mark more than one option. 
Regarding the dimensions of the nursing work process developed in current job or in which most professional work remained, 226 (78.2\%) indicated care, 106 (36.7\%), administrative, and 95 (32.9\%), teaching. Regarding current monthly income of research participants, most nurses $(152 ; 52.6 \%)$ receive 4 to 10 minimum wages, as shown in Table 3.

Regarding the level of satisfaction with the undergraduate nursing course, on a scale of 0 to 5,174 (55.4\%) students rated five, very satisfied, and 114 (36.3\%), four, satisfied, as shown in Figure 2.

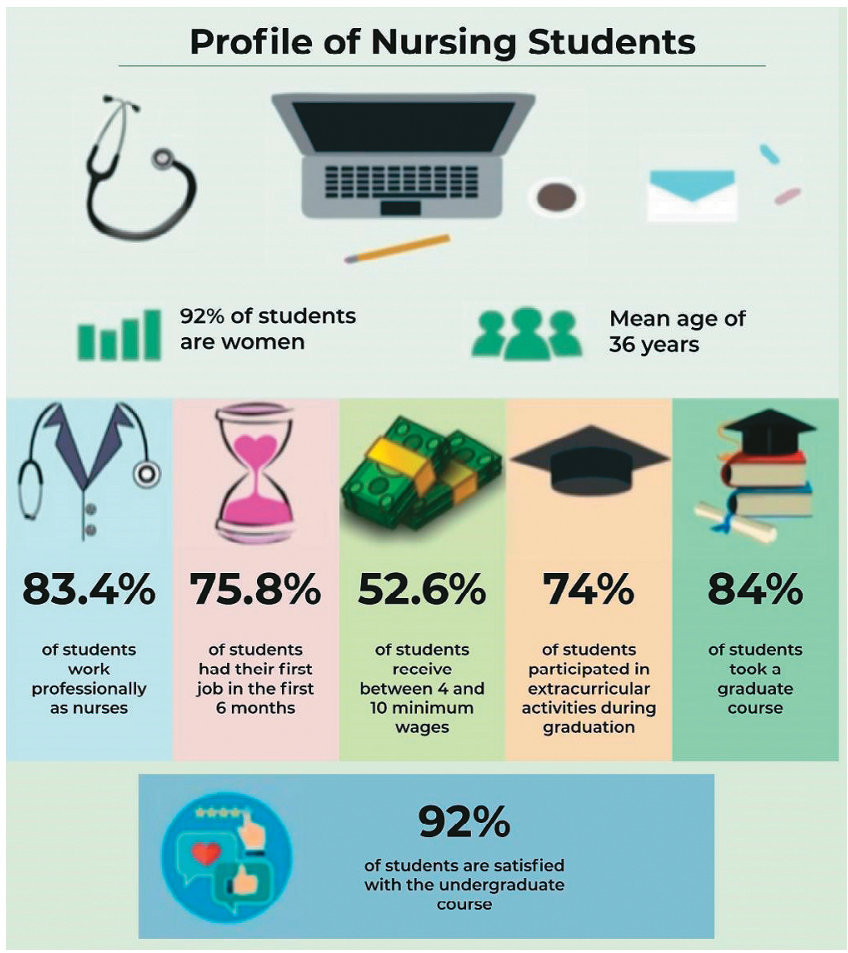

Figure 2 - Student profile and satisfaction with the undergraduate nursing course at a university in southern Brazil, Rio Grande, Rio Grande do Sul, Brazil, 2019

\section{DISCUSSION}

Data were collected over a period of 45 days, reaching almost $1 / 3$ of the study population. High adherence was evidenced by the number of instruments answered in a short period of time, compared to other studies with students ${ }^{(5,7-10)}$ who had difficulties in returning the answered instruments, requiring a longer data collection period. In a study carried out in São Paulo, data collection was carried out in eight months to obtain a minimum sample of 216 responses in a population of 470 students $^{(8)}$. In another, it took two years to obtain 66 responses from a population of 385 students ${ }^{(10)}$. The high adherence of this study may be directly related to the use of social networks for dissemination and participation of the target audience ${ }^{(11)}$.

Among the 314 participating students, most were female, with a mean age of 36 years, from southern Rio Grande do Sul. Regarding the predominance of women, the data support other studies $^{(8,10)}$. Furthermore, women account for around $87 \%$ of all nursing professionals in Brazil ${ }^{(13)}$. The permanence of most students in southern Rio Grande do Sul after graduation was also highlighted, a region where most indicated that they were born, graduated and worked as a nurse, a fact similar to other studies ${ }^{(1,9)}$. It is still relevant to consider that southeastern and southern Brazil have a greater number of nursing universities and these professionals in professional practice ${ }^{(2,14)}$.

However, even when considering the significant increase in the number of nurses in Brazil(1), it is necessary to emphasize that there is no proportional distribution of labor to serve the entire population, with a large concentration of professionals in the capitals of each state and an abandonment of less urbanized areas, which leads to an increase in inequalities in access to health, a fact that also accompanies the unequal distribution of universities with undergraduate and graduate degrees in nursing ${ }^{(2)}$.

Most students were on average 21 years old when they entered the course, through the entrance exam, and had no training in technical nursing or in any other undergraduate course. As in other studies ${ }^{(8,10,14)}$, admission to higher education in nursing had a predominance of increasingly younger people, which demonstrates a process of rejuvenation among professional nurses. Regarding having a technical course in nursing, different results were presented $^{(14)}$, which highlighted the previous training in a technical/assistance nursing course among students. However, the same study corroborates the data related to the small number of students who took another degree and defends the possibility that, among health courses, these are the first training option.

Regarding the variables of participation in activities during the training period, ten students indicated the realization of national and international exchange. In this sense, international ${ }^{(15)}$ and national mobility during graduation is relevant in the training process, as it favors both academic and sociocultural experiences, enabling the development of being a nurse in different contexts. In parallel, it was highlighted that more than $73 \%$ of students in this study participated in research and extension projects, followed by $65.6 \%$ who participated in teaching projects, corroborating another study, in which research and extension activities obtained indicative of $86 \%$ of 267 students involved ${ }^{(8)}$.

Also, in this study, more than $70 \%$ received a grant for the development of activities and $64 \%$ of students participated in research groups. The progressive increase in the number of nursing students who received scholarships during training is confirmed in another study ${ }^{(1)}$, a factor that can help in the exclusive dedication of students to the development of activities and permanence in the course. By providing an expanded environment of knowledge about the science of nursing ${ }^{(4)}$ that encourages the relationship between teachingresearch-service-community, providing students with experiences and challenges in real scenarios ${ }^{(16)}$, the result may be more qualified and prepared students to act and enter the labor market ${ }^{(4)}$.

Regarding the professional training process, most students $(83.8 \%)$ attended graduate studies and, of these, $84.6 \%$ opted for Lato Sensu specialization and $60.3 \%$ for Stricto Sensu academic master's degree. As a contribution, studies ${ }^{(7,14)}$ state that around $80 \%$ of nurses have taken some graduate course in nursing. However, discrepancy stands out, in which 160 students had taken Lato Sensu, while 11 had taken Stricto Sensu ${ }^{(7)}$. On the other hand, another study ${ }^{(8)}$ showed a lower percentage of those who completed graduate studies, around $40 \%$, but more similar in the number of students who opted for Stricto Sensu and Lato Sensu. Thus, when comparing the profile of students participating in this 
study, it is possible to evidence the approximation of interest in both qualification processes, which may be related to the interest in improving skills and expanding knowledge in the theoretical/ practical context in a continuous and certified manner, resulting in a qualified professional profile.

Entry into the labor market took place within six months after graduation for $75.8 \%$ of the students participating in this study. This data is relevant compared to other recent studies that obtained a percentage of around $50 \%$ of students employed in this period of time ${ }^{(8-9)}$ and even $67 \%$ within one year after graduation ${ }^{(8)}$. Demands for entry into the labor market have increased, causing students to mainly aspire to specialization courses and residencies that focus on qualification and improvement of technical skills for the transition between university and professional practice ${ }^{(9,17)}$. Also, based on the results presented, the participation of $73 \%$ of students in this study in different activities as project students and research groups is highlighted, whose premise is to enable the formation of a better prepared professional, with possibilities for better employability rates.

Regarding students' professional performance, $83.4 \%$ work professionally as nurses, $78.2 \%$ in care activities, $51.9 \%$ in hospital institutions, $51.9 \%$ as civil servants, $46 \%$ with a workload of 40 hours per week. Similar data were found in other studies, in which the significant portion that worked in care ${ }^{(8,14)}$ was public employees ${ }^{(5,7-9)}$, with a weekly workload of 40 hours on average ${ }^{(8,14)}$. With regard to wage income, it was possible to show that most nurses receive between four and ten minimum wages, taking into account the regional minimum wage in Rio Grande do Sul, which is $R \$ 1,196.47$ (about US\$217.54). The mean wage above $\mathrm{R} \$ 4,000$ (about US\$727.27) was evidenced in other studies ${ }^{(7-8)}$.

The health labor market in the public sector is expanding, considering the increase in the number of working professionals and the different working environments, related to the set of diverse actions in the field of health policy and services, which provided the need for professional nurses in different work contexts $^{(18)}$. Still, it is noteworthy that the hospital is considered the institution that employs the most nursing professionals ${ }^{(7,9,14)}$, which may be linked to the fact that the hospital area needs a larger number of professional nurses working, due to continuity of care within 24 hours a day.

Thus, students said they were very satisfied with the undergraduate nursing course, a fact that may be related to the high levels of involvement and participation in different activities during the academic training period, enabling positive repercussions in aspects related to learning and dropout. Therefore, investigating academic satisfaction is relevant in the process of planning and improving institutional programs and services and in qualifying the educational process ${ }^{(19)}$.

\section{Study limitations}

As limitations of this research, it is highlighted that it was not quantified which means of digital dissemination had the highest conversion by respondents and the impossibility of generalizations due to the study being carried out in a single context at a university in southern Brazil.

\section{Contributions to nursing, health, or public policy}

It is expected that the study will contribute to nursing from the increased participation in research by nursing students and consequently in the assessment of nurses' training process, in their insertion in the labor market, in addition to strengthening reflections on the need to develop new pedagogical proposals in undergraduate nursing courses.

\section{CONCLUSIONS}

From the social networks used in the methodology of this study, it was possible to overcome the difficulties of locating nursing students and also of returning the instruments during the data collection period. In this way, this study reached the minimum population established through statistical calculation in 45 days of data collection, making it possible to obtain 314 correctly answered instruments for analysis.

Therefore, this study made it possible to trace the profile of nursing students in the researched undergraduate nursing course: women, without technical/assistant training in nursing or other graduation, average age of 21 when entering the course, participants in scientific projects, research groups, with a scholarship grant. Furthermore, they attended a graduate course and obtained their first job within six months after graduation, they are clinical nurses, public servants, between 36 and 40 hours a week, in hospitals in southern Brazil, with a monthly income between four to ten minimum wages. Thus, the level of satisfaction of students stands out, more than $90 \%$ indicated being satisfied and/or very satisfied with the undergraduate nursing course.

The aspects presented represent important results of this study, since it is necessary to know the nursing students, seeking to understand professionals who completed their graduation in the studied institution, as well as to assess the weaknesses, strengths and contributions verified as a training institution, thus enabling the elaboration of new curriculum and pedagogical proposals.

\section{REFERENCES}

1. Wan Der Mass L. Análise comparativa da base social da medicina e enfermagem. Cad Saúde Pública. 2018;34(3):e00199116. https://doi. org/10.1590/0102-311x00199116

2. Frota MA, Wermelinger MCMW, Vieira LJES, Ximenes Neto FRG, Queiroz RSM, Amorim RF. Mapping nursing training in Brazil: challenges for actions in complex and globalized scenarios. Ciênc Saúde Coletiva. 2020; 25(1):25-35. https://doi.org/10.1590/1413-81232020251.27672019

3. Ministério da Educação (BR). Resolução CNE/CES n 3 de 7 de novembro de 2001. Institui Diretrizes curriculares nacionais do curso de graduação em enfermagem. Diário Oficial da União; 2001. 
4. Ximenes Neto FRG, Lopes Neto D, Cunha ICKO, Ribeiro MA, Freire NP, Kalinowski CE, et al. Reflections on Brazilian Nursing Education from the regulation of the Unified Health System. Ciênc Saúde Coletiva. 2020;25(1):37-46. https://doi.org/10.1590/1413-81232020251.27702019

5. Camelo S, Mishima S, Pereira M, Laus A, Porto H. Developing a nursing graduate follow-up methodology for a higher education institution. Rev Eletr Enf. 2015;17(2):247-56. https://doi.org/10.5216/ree.v17i2.28888

6. Lima LA, Andriola WB. Acompanhamento de egressos: subsídios para a avaliação de Instituições de Ensino Superior (IES). Rev Aval Educ Sup (Campinas). 2018;23(1):10125. https://doi.org/10.1590/s1414-40772018000100007

7. Oliveira L, Alves L, Carvalho P, Soares É. Trajetória profissional de egressos de enfermagem. Rev Interdiscip[Internet]. 2016 [cited 2020 Jul 17];9(1):125-34. Available from: https://revistainterdisciplinar.uninovafapi.edu.br/index.php/revinter/article/view/668

8. Barbosa ACS, Luiz FS, Friedrich DBC, Püschel VAA, Farah BF, Carbogim FC. Profile of nursing graduates: competencies and professional insertion. Rev Latino-Am Enfermagem. 2019;27:e3205. https://doi.org/10.1590/1518-8345.3222.3205

9. Püschel VAA, Costa D, Reis PP, Oliveira LB, Carbogim FC. Nurses in the labor market: professional insertion, competencies and skills. Rev Bras Enferm. 2017;70(6):1220-6. https://doi.org/10.1590/0034-7167-2016-0061

10. Araújo TAS, Reis PP, Castro C, Oliveira LB, Santos KB, Carbogim FC, Püschel VAA. Inserção profissional de Egressos da Licenciatura: avaliação quantitativa. Rev Paul Enferm. 2019;30. https://doi.org/10.33159/25959484.repen.2019v30a2

11. Costa BRL. Bola de Neve Virtual: O Uso das Redes Sociais Virtuais no Processo de Coleta de Dados de uma Pesquisa Científica. RIGS. 2018;7(1),15-37. https://doi.org/10.9771/23172428rigs.v7i1.24649

12. Hill M, Hill A. Investigação por Questionário. 2nd ed. Lisboa: Edições Sílabo; 2012.

13. Machado MH. Pesquisa Perfil da Enfermagem no Brasil: Relatório Final. Rio de Janeiro: Nerhus-Daps-Ensp/Fiocruz. [Internet] 2017. [cited 2020 Jul 17]. Available from: http://www.cofen.gov.br/perfilenfermagem/pdfs/relatoriofinal.pdf

14. Machado $M$, Wermelinger $M$, Vieira $M$, Oliveira $E$, Lemos W, Aguiar Filho W, et al. Aspectos gerais da formação da enfermagem: o perfil da formação dos enfermeiros técnicos e auxiliares. Enfermagem em Foco. 2016;7(ESP):15. https://doi.org/10.21675/2357-707X.2016.v7.nESP.687

15. Cavalcante IMS, Guedes GF, Püschel VAA. Nursing international student mobility in the University of São Paulo. Rev Bras Enferm. 2018;71(Suppl 4):1619-25. https://doi.org/10.1590/0034-7167-2017-0754

16. Amaral VF, Cavalcante ASP, Farias QLT, Ribeiro MA, Araújo JDG, Gomes DF. Mobilizando estudantes em defesa do Sistema Único de Saúde (SUS): experiências interprofissionais do VER-SUS - Sobral, CE, Brasil. Interface. 2018; 22(Suppl 2):1787-1797. https://doi. org/10.1590/1807-57622017.0715

17. Tyndall DE, Firnhaber GC, Scott ES. The Impact of New Graduate Nurse Transition Programs on Competency Development and Patient Safety. Adv Nurs Sci. 2018;41(4):26-52. https://doi.org/10.1097/ans.0000000000000217

18. Machado MH, Ximenes Neto FRG. Gestão da Educação e do Trabalho em Saúde no SUS: trinta anos de avanços e desafios. Cien Saude Colet. 2018; 23(6):1971-1979. https://doi.org/10.1590/1413-81232018236.06682018

19. Ramos AM, Barlem JGT, LVL, Barlem ELD, Silveira RS, Bordignon SS. Satisfaction with academic experience among undergraduate nursing students. Texto contexto - enferm. 2015;24(1):187-195. https://doi.org/10.1590/0104-07072015002870013 